Trusts and Patrimonies 


\section{EDINBURGH STUDIES IN LAW}

Series Editor

Elspeth Reid (University of Edinburgh)

Editorial Board

David L Carey Miller (University of Aberdeen)

George L Gretton (University of Edinburgh)

Hector L MacQueen (University of Edinburgh)

Kenneth G C Reid (University of Edinburgh)

Reinhard Zimmermann (Max-Planck Institute of Comparative and

International Private Law, Hamburg)

Volumes in the series:

Elspeth Reid and David L Carey Miller (eds), A Mixed Legal System in Transition: T B Smith and the Progress of Scots Law (2005)

Hector MacQueen and Reinhard Zimmermann (eds), European Contract Law: Scots and South African Perspectives (2006)

John W Cairns and Paul du Plessis (eds), Beyond Dogmatics:

Law and Society in the Roman World (2007)

William M Gordon, Roman Law, Scots Law and Legal History (2007)

Kenneth G C Reid, Marius J de Waal and Reinhard Zimmermann (eds), Exploring the Law of Succession: Studies National, Historical and Comparative (2007)

Vernon Valentine Palmer and Elspeth Christie Reid (eds), Mixed Jurisdictions Compared: Private Law in Louisiana and Scotland (2009)

J W Cairns and Paul du Plessis (eds), The Creation of the Ius Commune: From Casus to Regula (2010)

James Chalmers, Lindsay Farmer and Fiona Leverick (eds), Essays in Criminal Law in Honour of Sir Gerald Gordon (2010)

Elaine E Sutherland, Kay E Goodall, Gavin F M Little and Fraser P Davidson (eds), Law Making and the Scottish Parliament (2011)

Neil Walker (ed), MacCormick's Scotland (2012)

Eric Descheemaeker (ed), The Consequences of Possession (2014)

Remus Valsan (ed), Trusts and Patrimonies (2015)

John W Cairns, Law, Lawyers, and Humanism: Selected Essays on the History of Scots Law, Vol 1 (2015)

John W Cairns, Enlightenment, Legal Education, and Critique: Selected Essays on the History of Scots Law, Vol 2 (2015)

www.euppublishing.com/series/esil 


\title{
Trusts and Patrimonies
}

\author{
Edited by \\ Remus Valsan
}


(C) The Edinburgh Law Review Trust and the Contributors, 2015, for Chapters 1-4 and $6-10$

(C) The Edinburgh Law Review Trust, 2015, for selection and organisation of Chapter 5

Edinburgh University Press Ltd

The Tun - Holyrood Road

12 (2f) Jackson’s Entry

Edinburgh EH8 8PJ

www.euppublishing.com

Typeset in New Caledonia by

Servis Filmsetting Ltd, Stockport,

and printed and bound in Great Britain by

CPI Group (UK) Ltd, Croydon CR0 4YY

A CIP record for this book is available from the British Library

ISBN 9780748697748 (hardback)

ISBN 9780748697755 (webready PDF)

ISBN 9781474403535 (epub)

The right of the contributors to be identified as authors of this work has been asserted in accordance with the Copyright, Designs and Patents Act 1988 and the Copyright and Related Rights Regulations 2003 (SI No. 2498). 